\title{
CORRESPONDENCE ANALYSIS OF FRUIT AND VEGETABLE WASTE AMONG CONSUMERS IN VOJVODINA
}

Dragana N. Ubiparip Samek ${ }^{* 1}$, Lato L. Pezo ${ }^{1}$, Jasna S. Mastilović ${ }^{1}$, Renata M. Kovač ${ }^{1}$, Tihomir S. Zoranović ${ }^{1}$, Branislav I. Vlahović ${ }^{3}$

${ }^{1}$ University of Novi Sad, Institute of Food Technology, 21000 Novi Sad, Bulevar cara Lazara 1, Serbia

${ }^{2}$ University of Belgrade, Institute of General and Physical Chemistry, 11000 Beograd, Studentski trg 12/V, Serbia

${ }^{3}$ University of Novi Sad, Faculty of Agriculture, Department of Agricultural Economics, 21000 Novi Sad,

Trg Dositeja Obradovića 8, Serbia

\begin{abstract}
Fresh fruit and vegetables contribute to almost 50\% of food wasted by households in the EU. To understand the main reasons for wasteful behaviour among the consumers in Vojvodina (Serbia) cross-sectional data were collected through a self-administrated online survey of 711 correspondents. The questions presented in the study focused on the method of preserving the fruits and vegetables in domestic conditions before their consumption. Self-estimation of wasteful behaviour in the household and socio-demographic factors, including the respondents' selfestimated health status, were analysed using the correspondence analysis. The results showed that the first two dimensions explained for $95.06 \%$ of the total per cent of inertia (statistically significant at $\mathrm{p}<0.001$ level) indicating the strong relationship among variables. According to the survey, the fruit and vegetables are most likely used fresh $(54.43 \%$ and $48.95 \%$, respectively), whereas the use of fruits and vegetables after storage in a refrigerator $(17.16 \%$ and $29.96 \%$, respectively) or in a deep freezer ( $2.81 \%$ or $5.20 \%$, respectively) is significantly lower. Most of the survey correspondents claimed that they regularly discard the fruits and vegetables to waste (53.02\% and $39.66 \%$, respectively). The results pointed out that the storage and the amounts of discarded waste are affected by gender, income, and health conditions of the respondents'. Also, the study emphasized the growing need for educating and better planning of fresh fruit and vegetable management to reduce waste production.
\end{abstract}

Key words: fruit waste, vegetable waste, fruit storage, vegetable storage, wasteful behaviour

\section{INTRODUCTION}

Due to the rapid growth of the global population and the resources needed, the biggest challenge in the 21 st century represents feeding the population (Djekic, Miloradovic, Djekic \& Tomasevic, 2019) and guaranteed food security (De Laurentiis, Corrado \& Sala, 2018). On the other hand, the Food and Agriculture Organization of the United Nations has noted that one-third of all food produced for consumption is lost or wasted worldwide, 
which equals about 1.3 billion tons per year (FAO, 2011). The industrialized world generates more waste from food compared to the developing countries (FAO, 2011); consumers in Europe and North America waste $95-115 \mathrm{~kg}$ of food per person per year $(\mathrm{kg} / \mathrm{p} / \mathrm{y})$, while in sub-Saharan Africa and South/Southeast Asia, the amount is between 6 and $11 \mathrm{~kg} / \mathrm{p} / \mathrm{y}$ (FAO, 2011).

All this means significant losses of resources, additional negative environmental impact and changes in biodiversity (FAO, 2013). Food is lost or wasted throughout the supply chain, from agricultural production to final household consumption (FAO, 2011). Therefore, the United Nations focused on reducing the food losses by 2030 as a part of Sustainable Development Goals (United Nations, 2015), similarly to the European Commission, which prioritized food waste reduction within its Circular Economy Action Plan (European Commission, 2015).

Large amounts of food are wasted at the consumption level (Fami, Aramyan, Sijtsema \& Alambaigi, 2019), with households being the highest contributors to generating food waste (De Laurentiis et al., 2018).

According to Monier et al. (2010), approximately $180 \mathrm{~kg} / \mathrm{p} / \mathrm{y}$ of food are wasted every year in the EU, of which $101 \mathrm{~kg} / \mathrm{p} / \mathrm{y}$ are generated at the consumer level. Jensen et al. (2016) pointed out that total food waste generated at the European level is $173 \mathrm{~kg} / \mathrm{p} / \mathrm{y}$, out of which $92 \mathrm{~kg} / \mathrm{p} / \mathrm{y}$ are generated by households.

The contribution on fruits and vegetables $(\mathrm{F} \& \mathrm{~V})$ is estimated to be $31 \%$ of the total waste (including both households and food service), which is equal to $35.3 \mathrm{~kg} / \mathrm{p} / \mathrm{y}$ (Scherhaufer et al., 2015). Another study by Vanham, Bouraoui, Leip, Grizzetti and Bidoglio (2015) quantified food waste in the EU as $123 \mathrm{~kg} / \mathrm{p} / \mathrm{y}$, whereas $\mathrm{F} \& \mathrm{~V}$ are responsible for $63 \%$ of the total food waste generated. De Laurentiis et al. (2018) explained the high percentage of fresh $\mathrm{F} \& \mathrm{~V}$ in total food waste. Firstly, waste from fresh $\mathrm{F} \& \mathrm{~V}$ is composed of inedible components, oppositely to that of processed food, which undergoes discarding in all cases. These groceries are highly perishable products, often not consumed on time, and as relatively cheap commodities compared to other foodstuffs, consumers are more likely to be negligent about letting them spoil. According to Djekic et al., Serbia is a medium food waste polluter. Serbian households discard approximately 1.5 $\mathrm{kg}$ of food waste per week, including about 65 different pieces of food packaging (Djekic et al., 2019). Annually, Serbian households generate 198,712 tons of food waste. The main reason Serbian consumers create waste is related to food products with expired dates and observed rotten smells and tastes.

Reducing the amount of wasted food, especially $\mathrm{F} \& \mathrm{~V}$, became one of the crucial elements in developing a sustainable food system (Quested, Parry, Easteal \& Swannell, 2011), where final consumers play the most important role (Stenmarck et al., 2016). Therefore, this research focused on wasteful behaviour among the consumers in the north Serbian province of Vojvodina. The questions examined the methods of storing the fresh $\mathrm{F} \& \mathrm{~V}$ in domestic conditions before their consumption, including the self-estimation of wasteful behaviour in the households according to the socio-demographic factors and self-estimated health status of consumers in Vojvodina.

\section{MATERIALS AND METHODS}

\section{Survey design and data collection}

In order to collect the necessary data, this research was performed as a self-administrated online survey, in which the cross-sectional data were collected in Serbia's autonomous province of Vojvodina, with a sample of 711 respondents. The questionnaire was discussed with 20 consumers before presenting it to the actual respondents. Data were collected randomly to the population, which is close to hand, easily reachable and readily accessible. The online questionnaire was created using Survey Monkey, Inc. (San Mateo, California, USA) and the link was shared with the consumers via e-mails and social networks. Data were collected between September 2016 and May 2017. This research is a part of much broader research about fruit and vegetable consumption among consumers in Vojvodina. The first part of the questionnaire was related to socio-demographic characteristics of respondents, whereas the second to the questions concerning the methods of storing the fresh $\mathrm{F} \& \mathrm{~V}$ in domestic conditions before their consumption (1-fresh, 2-refrigerated and 3-frozen) and the self-estimation of wasteful behaviour in the households. Questionnaire items were 
measured on a 7 point Likert scale where 0 denotes "no answer", 1 "strongly disagree" and 7 "strongly agree" (Likert, 1932). The sample consisted of 754 respondents, of which 711 were chosen for the final sample as 41 had incomplete answers.

\section{Sample description}

The final sample of 711 participants consisted of $66 \%$ female, and $34 \%$ male respondents. This disproportion is probably related to the influence of women on purchases, decision making, including the impact on the diet of their family members (Belch \& Willis, 2002). Additionally, women consume more $\mathrm{F} \& \mathrm{~V}$ and have a higher level of knowledge about the importance of regular F\&V consumption (Blanck, Gillespie, Kimmons, Seymour \& Serdula, 2008). The majority of participants were between 25 and 45 years old (45\%). Participants under 25 years accounted for $30 \%$ while those between 45 and 65 years were $25 \%$. Half of the participants had college degrees and half did not. Approximately, the same level of respondents was married and single. Also, half of the respondents were employed, $26 \%$ of respondents had an average income in Serbia (between 250€ and 500€). According to these results, Vojvodina's population is presented in an adequate manner. Additionally, based on the self-reported height and weight, average BMI was calculated. Results showed that $70.32 \%$ of consumers had normal BMI. On the contrary, $29.54 \%$ of consumers were overweight. When asked about physical appearance, two-thirds of participants were satisfied, but one-third of them were not and they would like to change something about it. Most of them declared they would like to lose weight. Almost half of the participants declared they have a good state of health. Noteworthy, 26\% of participants didn't perform any type of physical activity or had poor physical activity, once a week (30\%).

\section{The First Order Polynomial Model (FOP model) and Analysis of variance (ANOVA)}

The FOP model was used for the estimation of the main effects of the socio-demographic characteristics of respondents on responses. The independent variables used for modelling were socio-demographic characteristics of respondents (gender, age, education, income, health, fitness, outlook, activity, and BMI), storing the fresh $\mathrm{F} \& \mathrm{~V}$ in domestic conditions before their consumption (1-fresh, 2-refrigerated and 3-frozen) and the self-estimation of wasteful behaviour in the households were the response variables. FOP model was fitted to data collected from the survey. ANOVA was conducted for obtained FOP model, and output was tested against the impact of input variables.

\section{Correspondence Analysis (CA)}

All the questions were analysed using CA as a useful statistical technique for analysing data collected in social surveys. It presents numerical tabular data in simple graphical presentation using scatter plot representation with a set of points with respect to two coordinate axes (Greenacre, 2017). CA with a symmetric normalization model (Hoffman \& Franke, 1986; Beh, 2004;) was performed using the statistical software Statistica 12 (StatSoft, Tulsa, OK, USA).

\section{RESULTS AND DISCUSSION}

For the $\mathrm{F} \& \mathrm{~V}$ waste analysis, eight questions were created. Each participant evaluated F\&V consumption by choosing the score for consumption of the specific method of preserving F\&V before consumption (1-fresh, 2 - in refrigerator, 3 - in deep freezer) since adequate temperature management is the simplest and easiest way to delay the decay of these groceries (Nunes et al., 2009). The self-reported $\mathrm{F} \& \mathrm{~V}$ waste behaviour is also evaluated in the survey. Food waste, including F\&V waste, occurs in all stages of the supply chain from agricultural production to final consumption (Pelau, Sarbu \& Serban, 2020), but the biggest part of the waste comes from the final consumers, at the household level (Garcia-Herrero et al., 2018). F\&V waste occurs mostly due to its short shelf-life (McCarthy \& Liu, 2017).

Results obtained in this study are presented in Table 1 and the answers were measured on a 7 point Likert scale: 0 - no answer, 1 - "strongly disagree" and 7 - "strongly agree").

ANOVA results for the obtained FOP model are presented in the Table 2. Analysis revealed that the linear terms considerably influenced forming of FOP model for HHF1, HHF2, HHF3, OF1, HHV1, HHV2, HHV3, and OV1 calculation (Table 3). According to ANOVA results for fruits, HHF1 was mostly affected by gender $(p<0.05)$ as wo-men more often store fresh fruits at room temperature than men who prefer to keep them in a refrigerator or a freezer HHF2 was influenced mostly by income 
Table 1.

Answers ${ }^{*}$ to questions (\% of respondents) from the survey on F\&V waste generation analysis in Vojvodina

\begin{tabular}{|c|c|c|c|c|c|c|c|c|}
\hline $\begin{array}{l}\text { Likert } \\
\text { scale } \\
\text { points }\end{array}$ & 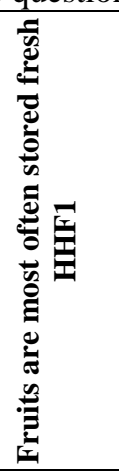 & 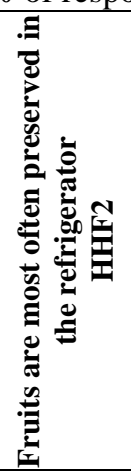 & 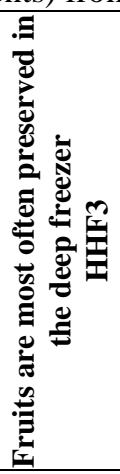 & 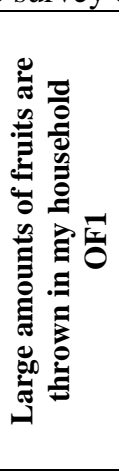 & 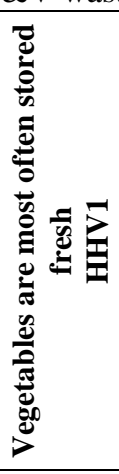 & 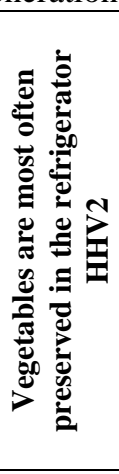 & 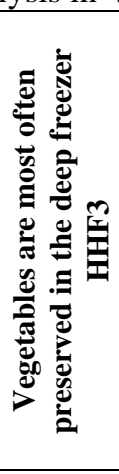 & 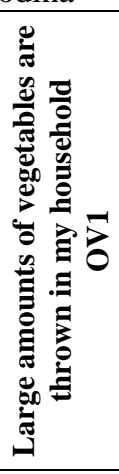 \\
\hline $\mathbf{0}$ & 1.0 & 2.4 & 1.5 & 0.0 & 2.3 & 1.5 & 2.8 & 0.0 \\
\hline 1 & 3.7 & 17.4 & 40.1 & 5.2 & 2.5 & 5.1 & 17.2 & 4.8 \\
\hline 2 & 2.1 & 12.9 & 25.3 & 4.1 & 3.2 & 5.5 & 19.7 & 7.7 \\
\hline 3 & 3.0 & 11.7 & 13.5 & 4.2 & 3.2 & 10.8 & 20.1 & 10.1 \\
\hline 4 & 9.14 & 17.6 & 11.2 & 8.8 & 9.5 & 14.9 & 19.7 & 11.8 \\
\hline 5 & 9.1 & 9.8 & 4.2 & 9.1 & 12.5 & 16.0 & 10.0 & 13.1 \\
\hline 6 & 17.6 & 11.0 & 1.3 & 14.2 & 17.7 & 16.2 & 5.3 & 11.7 \\
\hline 7 & 54.4 & 17.2 & 2.8 & 53.0 & 48.9 & 30.0 & 5.2 & 39.7 \\
\hline
\end{tabular}

Table 2.

The effects of the socio-economic variables on the responses

\begin{tabular}{|c|c|c|c|c|c|c|c|}
\hline Variables & HHF1 & HHF2 & HHF3 & OF1 HHV1 & HHV2 & HHV3 & OV1 \\
\hline Gender & $*$ & $* *$ & & + & & & + \\
\hline Age & & & & & & & $*$ \\
\hline Education & & $* *$ & & & & & \\
\hline Income & & $*$ & & & $* *$ & & \\
\hline Health & & & & & $*$ & & \\
\hline Fitness & & & $*$ & & $*$ & $* *$ & $* *$ \\
\hline Outlook & & & & $*$ & $* *$ & & \\
\hline Activity & $* *$ & & & & & & \\
\hline BMI & & & & $* *$ & * & & \\
\hline
\end{tabular}

+significant at $p<0.01$ level; * significant at $p<0.05$ level; **statistically insignificant

$(\mathrm{p}<0.05)$ whereas consumers with higher income more often store the fruits in a refrigerator, in contrast to those with lower income. HHF3 was also significantly influential $(p<0.05)$ by self-estimation of health status and fitness level. Consumers who estimated their health status as bad and, contrary, those with excellent fitness status, preserved fruits by freezing. OF1 was mostly affected by gender $(p<0.01)$ and outlook $(p<0.05)$. The results show that women throw higher amounts of fruits compared to men. Older consumers also tend to throw more fruits than the younger population (Table 3 ).

The results for vegetables showed that HHV1 was influenced by self-estimation of health status, physical activity and BMI $(\mathrm{p}<0.05)$, while OV1 was influenced by gender $(\mathrm{p}<0.01)$ and age $(\mathrm{p}<0.05)$. This means that consumers with poor health conditions, less physical activity and a normal BMI index more often tend to preserve vegetables in the refrigerator. Similarly to OF1, OV1 was also affected by gender and age; women and older consumers throw more vegetables into waste (Table 3).

According to correlation analysis, the answers obtained for the question HHF1 negatively correlated to HHF3 ( $p<0.05$ level) but positively correlated to OF1, HHV1 and HHV2 $(\mathrm{p}<0.01)$. 
Table 3.

Mean values of the respondents' answers

\begin{tabular}{|c|c|c|c|c|c|c|c|c|c|}
\hline Variables & & HHF1 & HHF2 & HHF3 & OF1 & HHV1 & HHV2 & HHV3 & OV1 \\
\hline \multirow[t]{2}{*}{ Gender } & male & 5.7 & 4.0 & 2.4 & 5.3 & 5.5 & 4.9 & 3.1 & 4.8 \\
\hline & female & 6.0 & 3.8 & 2.2 & 6.0 & 5.8 & 5.0 & 3.1 & 5.4 \\
\hline \multirow[t]{3}{*}{ Age } & $<25$ & 5.8 & 3.5 & 2.3 & 5.5 & 5.5 & 4.7 & 3.1 & 4.9 \\
\hline & $25-45$ & 5.9 & 4.0 & 2.3 & 5.8 & 5.9 & 5.2 & 3.3 & 5.3 \\
\hline & $>45$ & 5.9 & 4.0 & 2.2 & 6.0 & 5.6 & 4.8 & 2.9 & 5.4 \\
\hline \multirow[t]{2}{*}{ Education } & elementary or high school & 5.9 & 3.7 & 2.3 & 5.9 & 5.7 & 4.8 & 3.1 & 5.3 \\
\hline & college & 5.8 & 4.0 & 2.2 & 5.6 & 5.7 & 5.1 & 3.1 & 5.1 \\
\hline Household & $<50.000 \mathrm{RSD}$ & 5.8 & 3.5 & 2.3 & 5.9 & 5.8 & 4.7 & 3.2 & 5.4 \\
\hline income & $>50.000 \mathrm{RSD}$ & 5.9 & 4.0 & 2.2 & 5.6 & 5.6 & 5.1 & 3.1 & 5.1 \\
\hline \multirow[t]{3}{*}{ Health } & bad & 5.3 & 4.7 & 2.7 & 5.5 & 5.9 & 5.2 & 3.2 & 5.0 \\
\hline & good & 5.8 & 3.9 & 2.2 & 5.8 & 5.6 & 4.8 & 3.1 & 5.3 \\
\hline & excellent & 6.0 & 3.7 & 2.2 & 5.8 & 5.7 & 5.1 & 3.2 & 5.2 \\
\hline \multirow[t]{3}{*}{ Fitness } & bad & 5.5 & 4.2 & 2.1 & 5.7 & 5.7 & 5.2 & 3.2 & 5.0 \\
\hline & good & 6.0 & 3.8 & 2.3 & 5.8 & 5.7 & 4.9 & 3.2 & 5.3 \\
\hline & excellent & 5.9 & 3.7 & 2.4 & 5.7 & 5.7 & 4.8 & 3.1 & 5.2 \\
\hline \multirow[t]{3}{*}{ Outlook } & not satisfied & 5.8 & 4.2 & 2.4 & 5.4 & 5.7 & 5.3 & 3.1 & 5.2 \\
\hline & satisfied & 5.9 & 3.7 & 2.1 & 6.0 & 5.8 & 4.8 & 3.3 & 5.2 \\
\hline & I would change something & 5.9 & 3.8 & 2.3 & 5.7 & 5.7 & 4.9 & 3.1 & 5.2 \\
\hline \multirow[t]{3}{*}{ Activity } & not active/ 1-2 per week & 5.7 & 4.0 & 2.2 & 5.8 & 5.7 & 5.0 & 3.2 & 5.2 \\
\hline & 3-4 per week & 6.1 & 3.7 & 2.3 & 5.6 & 5.6 & 4.9 & 3.1 & 5.2 \\
\hline & 5-6 per week/every day & 6.1 & 3.7 & 2.5 & 5.7 & 5.7 & 4.8 & 3.2 & 5.3 \\
\hline \multirow[t]{2}{*}{ BMI } & normal & 5.9 & 3.8 & 2.2 & 5.7 & 5.7 & 5.0 & 3.1 & 5.3 \\
\hline & overweight & 5.7 & 4.0 & 2.4 & 5.8 & 5.7 & 4.8 & 3.2 & 5.1 \\
\hline
\end{tabular}

* In table were presented mean values of the respondents' answers

This suggests that correspondents usually store fruits as fresh and not in a deep freezer. Consequently, a large number of fresh fruits are thrown to waste. When it comes to vegetables, consumers usually store them as fresh. One of the reasons might be that consumers perceive frozen vegetables as less healthy and tasty compared to their fresh counterparts (Ubiparip Samek et al., 2021). On the other hand, freezing fresh commodities can be a good household practice for preserving their nutritional value and overcoming the seasonal character of fresh products (Rickman, Barrett \& Bruhn, 2007).

HHF2 positively correlated to HHF3, HHV2, and HHV3, and negatively to OV1 $(\mathrm{p}<0.01$ level). Respondents, who store fresh fruits and vegetables in refrigerated or freezing conditions, tend to produce less vegetable waste. A good strategy to reduce $\mathrm{F} \& \mathrm{~V}$ waste might be to educate consumers to use more processed products which can be cheaper and easier to use. Moreover, frozen products usually do not have much lower nutritional value compared to fresh products ( $\mathrm{Li}$, Pegg, Eitenmiller, Chun \&Kerrihard, 2017).

\section{Correspondence Analysis}

The reasons for consuming the specific type of the preserved fruits and vegetables according to questions HHF1, HHF2, HHF3, OF1, HHV1, HHV2, HHV3, and OV1 were used in the correspondence analysis and the results are summarized according to the offered answers listed in Table 1. Graphical presentation of correspondence analysis is presented in Fig. 1. A significant correspondence $(\mathrm{p}<0.001)$ was found among the considered categories, representing the total inertia of 0.401 and $\chi^{2}$ value of $2279(\mathrm{df}=56)$. The first two dimensions account for $95.06 \%$ of the total inertia, using a considerably satisfactory quota of the raw information.

The biplot (Fig. 1) shows a substantial differrentiation among reasons for consumption of different kinds of preserved $\mathrm{F} \& \mathrm{~V}$. In general, all categories were clearly distinguished one from the other. Numbers from 1 (the lowest value) to 7 (the highest level) represent values on a 7-point Likert scale. F\&V are mostly (value 7) consumed fresh $(54.4 \%$ and $48.9 \%$, respectively) compared to their preservation in the refrigerator (17.2\% and 30\%) and deep freezer $(2.8 \%$ and $5.2 \%)$ (Table 1). Moreover, fruits are more often discarded into waste compared to vegetables. This wasteful behaviour is confirmed in many studies. Djekic et al. (2019) 


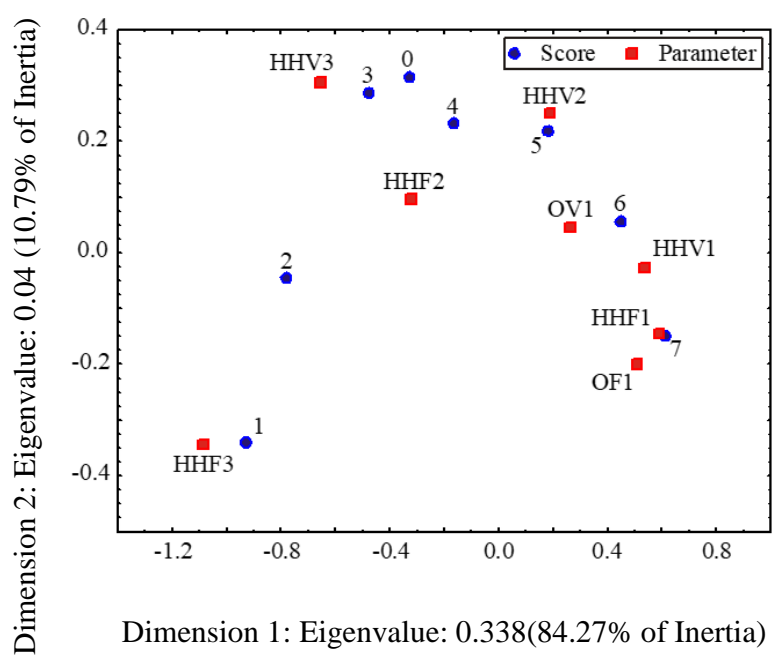

Figure 1. Biplot - Correspondence between the scores obtained by the survey responder and the specific questions regarding the use for consuming the specific type of the preserved fruit and vegetables

stated many reasons for wasting food which can be related to food and vegetable waste. They are related to ethical and environmental concerns, purchasing behaviour, food preparation and expiration date. For example, in order to reduce waste, specific labels should be used for $\mathrm{F} \& \mathrm{~V}$ sold in the supermarkets providing information about name, variety, country of origin, production area, treatments used, recommended use, nutritional value, production and preservation method, preparation recommendation, best before date, packing date, harvest date, beneficial properties etc. (Fernández-Serrano, Tarancón \& Besada, 2021). On the other hand, when buying $F \& V$ in the open market and directly from farmers consumers are not familiar with that information and the only method to estimate F\&V shelf life is visual, which might lead to higher amounts of waste. Additionally, consumers' careless attitude toward food, insufficient knowledge about food management and storage, lack of purchasing planning and excessive cooking could also be some of the reasons for excessive waste (Revilla \& Salet, 2018). In order to reduce the amounts of $F \& V$ waste generated, it is necessary to develop educative policies and programs which will include various producers, stakeholders, retailers and, finally, the consumers in order to stimulate the development of better consumption habits.

\section{CONCLUSIONS}

Food waste in general, including F\&V waste, is a global problem due to its impact on food security, economy and environment. Vojvo- dina, as a significant part of the Republic of Serbia, is not an exception. In order to reduce waste at a household level, besides good collaboration throughout the complete F\&V supply chain, it is necessary to focus on consumers as well, since many campaigns have limited consumers' engagement. Different educational campaigns should be created in order to stimulate the consumers in behavioural changes, by providing them with enough informative material, different food recipes, as well as the technology usage, in order to obtain maximal usability from specific fresh or processed $F \& V$. Campaigns that include consumers should promote healthier, more effective and sustainable strategies to achieve permanent positive change in dietary habits, which will in turn also result in a decreasing trend of food waste generation.

\section{ACKNOWLEDGEMENTS}

This work was financially supported by the Ministry of Education, Science and Technological Development (Serbia) under the Agreement on the Implementation and Financing of Research of the Institute of Food Technology (No.451-03-9/2021-14/200222).

\section{REFERENCES}

Beh, E. J. (2004). Simple correspondence analysis: A bibliographic review. International Statistical Review, 72(2), 257-284.

Belch, M. A., \& Willis, L. A. (2002). Family decision at the turn of the century: Has the changing structure of households impacted the family decisionmaking process? Journal of Consumer Behaviour: An International Research Review, 2(2), 111-124. https://doi.org/10.1002/cb.94 
Blanck, H. M., Gillespie, C., Kimmons, J. E., Seymour, J. D., \& Serdula, M. K. (2008). Trends in fruit and vegetable consumption among US men and women, 1994-2005. Preventing Chronic Disease, 5(2). Retrieved Dec. 2020, from https://www.ncbi.nlm.nih.gov/pmc/articles/PMC23 96974/

De Laurentiis, V., Corrado, S., \& Sala, S. (2018). Quantifying household waste of fresh fruit and vegetables in the EU. Waste management, 77, 238-251. https://doi.org/10.1016/j.wasman.2018.04.001

Djekic, I., Miloradovic, Z., Djekic, S., \& Tomasevic, I. (2019). Household food waste in Serbia - Attitudes, quantities and global warming potential. Journal of Cleaner Production, 229, 44-52. https://doi.org/10.1016/j.jclepro.2019.04.400

European Commission. (2015). Closing the loop - An EU action plan for the Circular Economy. Communication from the Commission to the European Parliament, the Council, the European Economic and Social Committee and the Committee of the Regions. Brussels. Retrieved Sept. 20, 2021, from https://eur-lex.europa.eu/legalcontent/EN/TXT/?uri=CELEX\%3A52015DC0614

Fami, H. S., Aramyan, L. H., Sijtsema, S. J., \& Alambaigi, A. (2019). Determinants of household food waste behaviour in Tehran city: A structural model. Resources, Conservation and Recycling, 143, 154166. htps://doi.org/10.1016/j.resconrec.2018.12.033

FAO (2011). Global food losses and food waste - Extent, causes and prevention. FAO, Rome. Retrieved Sept. 20, 2021, from http://www.fao.org/3/mb060e/mb060e.pdf.

FAO (2013). Food Wastage Footprint; Impacts on Natural Resources. FAO, Rome, p.63. Retrieved Sept. 20, 2021, from

http://www.fao.org/publications/card/en/c/000d4a3 2-7304-5785-a2f1-f64c6de8e7a2/

Fernández-Serrano, P., Tarancón, P., \& Besada, C. (2021). Consumer information needs and sensory label design for fresh fruit packaging. An exploratory study in Spain. Foods, 10(1), 72. https://doi.org/10.3390/foods10010072

Garcia-Herrero, I., Hoehn, D., Margallo, M., Laso, J., Bala, A., Batlle-Bayer, L., Fullana, P., VasquezRowe, I., Gonzalez, M. J., Durá, M. J., Sarabia, C., Abajas, R. Amo-Setien, F. J., Quiñones, A., Irabien, A. \& Aldaco, R. (2018). On the estimation of potential food waste reduction to support sustainable production and consumption policies. Food Policy, 80, 24-38. https://doi.org/10.1016/j.foodpol.2018.08.007

Greenacre, M. (2017). Correspondence analysis in practice. New York, NY: Chapman and Hall/CRC. Retrieved on Sept. 2018 from https://www.taylorfrancis.com/books/mono/10.120 1/9781315369983/correspondence-analysispractice-michael-greenacre

Hoffman, D. L., \& Franke, G. R. (1986) Correspondence analysis: Graphical representation of categorical data in marketing research. Journal of Marketing Research, 23(3): 213-227.

https://doi.org/10.1177/002224378602300302 https://doi.org/10.1111/j.1751-823.2004.tb00236.x

Jensen, C., Quested, T., Moates, G., Buksti, M., Cseh, B., et al. (2016). Estimates of European food waste levels (Project report on FUSIONS). [Contract]
31032016, 2016. 〈hal-02801611〉. Göteborg, Sweden: SIK - The Swedish Institute for Food and Biotechnology. Retrieved Sept. 20, 2021, from https://hal.inrae.fr/hal-02801611

Li, L., Pegg, R. B., Eitenmiller, R. R., Chun, J. Y., \& Kerrihard, A. L. (2017). Selected nutrient analyses of fresh, fresh-stored, and frozen fruits and vegetables. Journal of Food Composition and Analysis, 59, 8-17.

https://doi.org/10.1016/j.jfca.2017.02.002

Likert, R. (1932). A technique for the measurement of attitudes. Archives of Psychology, 22(140), 55. Retrieved Dec. 2020, from https://psycnet.apa.org/record/1933-01885-001

McCarthy, B., \& Liu, H. B. (2017). Food waste and the 'green' consumer. Australasian Marketing Journal (AMJ), 25(2), 126-132. https://doi.org/10.1016/j.ausmj.2017.04.007

Monier, V., Mudgal, S., Escalon, V., O'Connor, C., Gibon, T., Anderson, G., \& Morton, G. (2010). Preparatory study on food waste across EU 27. Report for the European Commission (DG ENV Directorate C) BIO Intelligence Service (BIOIS), Paris.

https://ec,europa.eu/environment/eussd/pdf/bio_foo dwaste_report.pdf.

Nunes, M. C. N., Emond, J. P., Rauth, M., Dea, S., \& Chau, K. V. (2009). Environmental conditions encountered during typical consumer retail display affect fruit and vegetable quality and waste. Postharvest Biology and Technology, 51(2), 232-241. https://doi.org/10.1016/j.postharvbio.2008.07.016

Pelau, C., Sarbu, R., \& Serban, D. (2020). Cultural influences on fruit and vegetable food-wasting behavior in the European Union. Sustainability, 12(22), 9685. https://doi.org/10.3390/su12229685

Quested, T. E., Parry, A. D., Easteal, S., \& Swannell, R. (2011). Food and drink waste from households in the UK. Nutrition Bulletin, 36(4), 460-467. https://doi.org/10.1111/j.1467-3010.2011.01924.x

Revilla, B. P., \& Salet, W. (2018). The social meaning and function of household food rituals in preventing food waste. Journal of Cleaner Production, 198, 320-332. https://doi.org/10.1016/j.jclepro.2018.06.038

Rickman, J. C., Barrett, D. M., \& Bruhn, C. M. (2007). Nutritional comparison of fresh, frozen and canned fruits and vegetables. Part 1. Vitamins C and B and phenolic compounds. Journal of the Science of Food and Agriculture, 87(6), 930-944. https://doi.org/10.1002/jsfa.2825

Scherhaufer, S., Lebersorger, S., Pertl, A., Obersteiner, G., Schneider, F., Falasconi, L., De Menna, F., Vittuari, M., Hartikainen, H., Katajajuuri, J. M., \& Joensuu, K. (2015). Criteria for and baseline assessment of environmental and socio-economic impacts of food waste. BOKU University of Natural Resources and Life Sciences, Institute of Waste Management. http://eu-fusions.org/index.php/download?download $=182$ : criteria-for-andbaseline-assessment-of-environmental-and-socioeconomic-impacts-of-food-waste

Ubiparip-Samek, D. N., Bajić, A. R., Pezo, L. L., Kovač, R. M., Mastilović, J. S., Zoranović, T. S., \& Vlahović, B. I. (2021). Exploring consumer preferences and factors associated with vegetable con- 
Dragana N. Ubiparip Samek et. al., Correspondence analysis of fruit and vegetable waste among consumers in Vojvodina, Food and Feed Research, 48 (2), 1-9, 2022

sumption. Food and Feed Research, 48(1), 57-68. https://doi.org/10.5937/ffr48-32587

United Nations. (2015). Sustainable development goals. 17 goals to transform our world. Retrieved Sept. 20, 2021, from

http://www.un.org/sustainabledevelopment/oceans/
Vanham, D., Bouraoui, F., Leip, A., Grizzetti, B., \& Bidoglio, G. (2015). Lost water and nitrogen resources due to EU consumer food waste. Environmental Research Letter, 10(8), 1-16.

https://doi.org/10.1088/1748-9326/10/8/084008 


\section{ANALIZA BACANJA VOĆA I POVRĆA MEĐU POTROŠAČIMA U VOJVODINI}

Dragana N. Ubiparip Samek ${ }^{* 1}$, Lato L. Pezo ${ }^{1}$, Jasna S. Mastilović ${ }^{1}$, Renata M. Kovač ${ }^{1}$, Tihomir S. Zoranović ${ }^{1}$, Branislav I. Vlahović ${ }^{3}$

${ }^{1}$ Univerzitet u Novom Sadu, Naučni institut za prehrambene tehnologije, 21000 Novi Sad,

Bulevar cara Lazara 1, Srbija

${ }^{2}$ Univerzitet u Beogradu, Institut za opštu i fizičku hemiju, 11000 Beograd, Studentski trg 12/V, Srbija

${ }^{3}$ Univerzitet u Novom Sadu, Poljoprivredni fakultet, Departman za ekonomiku poljoprivrede i sociologiju sela, 21000 Novi Sad, Trg Dositeja Obradovića 8, Srbija

Sažetak: Sveže voće i povrće čine čak do $50 \%$ ukupno bačene hrane od strane domaćinstava u okviru Evropske unije. Kako bi se objasnili glavni razlozi ovakvog ponašanja među potrošačima u Vojvodini (Srbija) sprovedeno je online istraživanje putem ankete među 711 ispitanika. Pitanja predstavljena u ovom istraživanju naglašavaju metode čuvanja voća i povrća u kućnim uslovima pre njihove konzumacije. Samoprocena bacanja voća i povrća u okviru domaćinstva i samoprocena zdravstvenog stanja potrošača su analizirani primenom analize korespondencije. Dobijeni rezultati pokazuju da prve dve dimenzije objašnjavaju 95,06\%ukupne inercije ( $<<0.001$ ), što ukazuje na jaku vezu među posmatranim varijablama. Na osonvu ankete može se zaključiti da se i voće i povrće najčešće konzumiraju u svežem stanju (54,43\% i 48,95\%, respektivno), dok je konzumacija voća i povrća iz frižidera $(17,16 \%$ i $29,96 \%$, respektivno), odnosno iz zamrzivača $(2,81 \%$ i $5,20 \%$, respektivno) značajno niža. Većina ispitanika navodi da redovno bacaju voće i povrće $(53,02 \%$ i $39,66 \%$, respektivno). Rezultati ističu da količina voća i povrća koja se baci zavise od pola, nivoa dohotka i zdravstvenog stanja ispitanika. Sve ovo ukazuje na neophodnost intenzivnije edukacije potrošača i boljim postupanjem sa ovim namirnicama, kako bi se smanjio otpad.

Ključne reči: bacanje voća, bacanje povrća, čuvanje voća, čuvanje povrća, ponašanje potrošača

Received:14 November 2021/Received in revised form: 05 January 2022/ Accepted:19 January 2022

Available online: January 2022

This is an open-access article under the CC BY license (http://creativecommons.org/licenses/by/3.0). 